\title{
Chasma Australe, Mars: Structural Framework for a Catastrophic Outflow Origin
}

\author{
Francisco Anguita \\ Departamento de Petrología y Geoquímica, Facultad de Ciencias Geológicas, Universidad Complutense, 28040 Madrid, Spain \\ E-mail: anguita@eucmax.sim.ucm.es
}

Rosa Babín

Departamento de Geodinámica, Facultad de Ciencias Geológicas, Universidad Complutense, 28040 Madrid, Spain

Gerardo Benito

Environmental Sciences Center, Consejo Superior de Investigaciones Científicas, 28006 Madrid, Spain

David Gómez

Departamento de Geodinámica, Facultad de Ciencias Geológicas, Universidad Complutense, 28040 Madrid, Spain

Ana Collado

Seminario de Ciencias Planetarias, Facultad de Ciencias Geológicas, Universidad Complutense, 28040 Madrid, Spain

and

James W. Rice

Lunar and Planetary Laboratory, Arizon State University, 1629 E University Boulevard, P.๑. Box 210092, Tucson, Arizona 85721 -0092

Chasma Australe, $500 \mathrm{~km}$ long and up to $80 \mathrm{~km}$ wide, is the most remarkable of the martian south pole erosional reentrants carved in the polar layered deposits. We have interpreted Chasma Australe erosional and depositional features as evidence for a flood origin, which we have reconstructed using a modified Manning equation. The main characteristics of the flow are a water velocity between 30 and $50 \mathrm{~m} \mathrm{~s}^{-1}$ and discharge values between $7 \times 10^{8}$ and $3 \times$ $10^{9} \mathrm{~m}^{3} \mathrm{~s}^{-1}$, very near to MGS data-based estimations for martian outflow channels (D. E. Smith et al. 1998, Science 279, 1686-1692). We thus postulate that Chasma Australe originated in a catastrophic flood.

The tectonic study of an area (roughly 20 million $\mathrm{km}^{2}$ in size) around Mars' south pole included the measurement and projection in rose diagrams of more than 300 lineaments, of which 85 were wrinkle ridges and the rest straight scarps. The whole set of lineaments can be explained by a stress field with a $\sigma_{1} \mathrm{~N} 10^{\circ} \mathrm{E}$ in strike, the wrinkle ridges being reverse faults and the other lineaments direct and strike-slip faults. The straight layout of parts of Chasma Australe almost $200 \mathrm{~km}$ long suggests that the chasma was carved following a fracture network. The effectiveness of the erosional process (the canyon is up to $1000 \mathrm{~m}$ deep) leads us to suspect that this carving was preceded by a sapping period. Endogenetic and exo- genetic processes would thus have contributed to the origin of this landform.

Key Words: Mars; tectonics; climate; poles.

\section{INTRODUCTION}

Chasma Australe, the most conspicuous polar reentrant carved in Mars' polar layered deposits (PLD), is a canyon (Fig. 1) $500 \mathrm{~km}$ long, 20 to $80 \mathrm{~km}$ wide, and up to $1000 \mathrm{~m}$ deep, which begins at a point some $270 \mathrm{~km}$ from the south pole and shows a general northerly direction. Its overall shape follows a gentle arc curved about $40^{\circ}$ westward; but its margins, and especially the eastern one, are straight in sections up to $180 \mathrm{~km}$ long. The dark, stepped troughs characteristic of the PLD are cut by the chasma, while the unit Hdu, Upper Member, Dorsa Argentea Formation of Tanaka and Scott (1987) form the bottom of the canyon, whose mouth is almost closed by a prominent hard spur.

No specific origin has yet been proposed for Chasma Australe. In general, polar troughs and reentrants have been attributed to the action of wind (e.g., Cutts 1973a,b, Howard 1978) or, in 


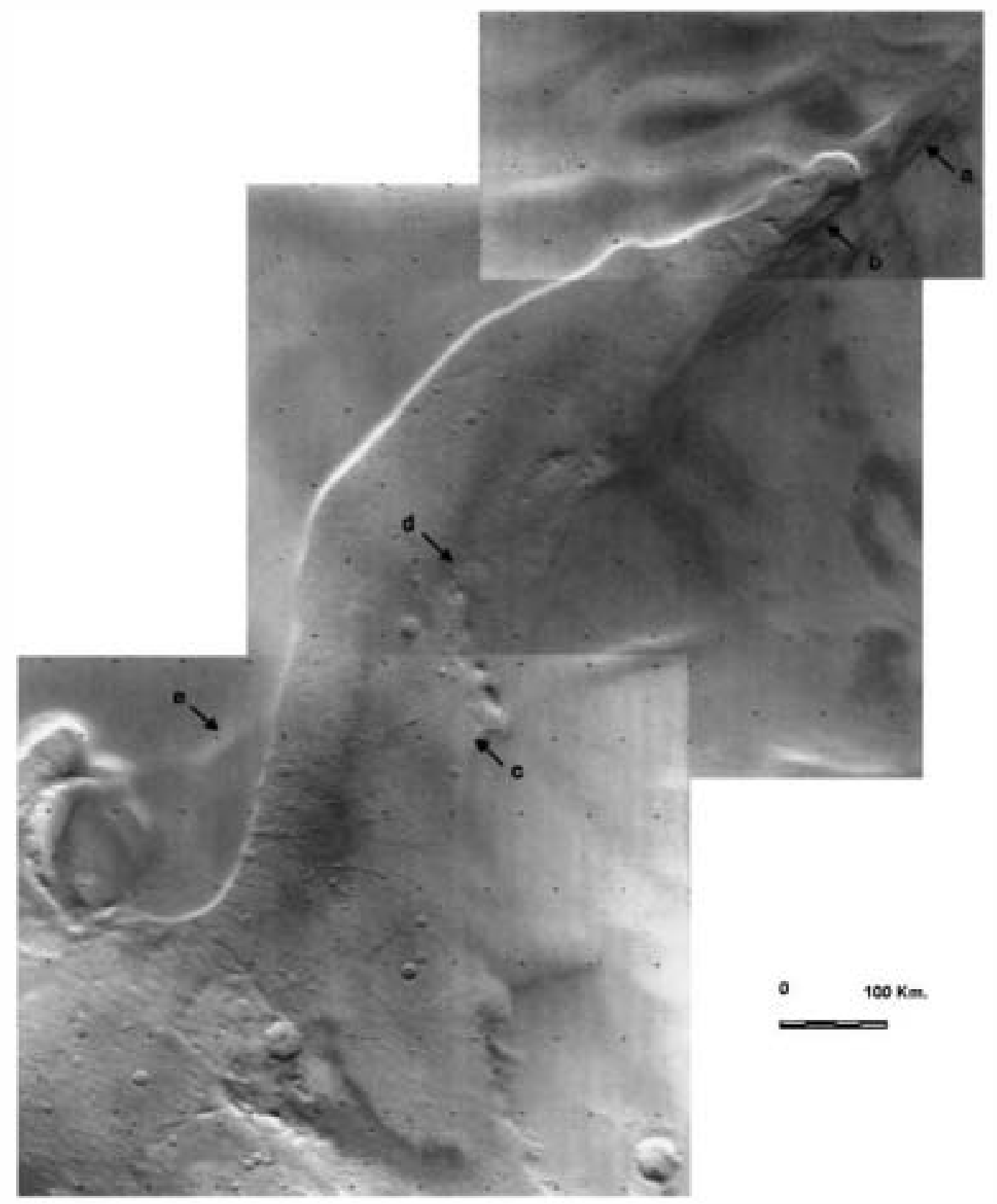

FIG. 1. Chasna Australe mesaic composed of Viking frames 383 $46,383 \mathbf{E} 48$, and $383 \mathbf{E} 5$

some restricted instances (Wallace and Sagan 1979, Clifford $1980,1987)$, of water. Cliffor $(1980,1987)$ and Benito et al. (1997) proposed a thermal event under the ice (jökulhlaup) for the orig in of Chasma Boreale, ac anyon whose generalmorphologybears a great similarity with Chasma Australe: both present a horseshoe-shaped headwater cliff, an asymmetric valley topography in the middle reach, and a broad terminal area.

hivestigating the origin of the polar reentrants could be fiuitful in at least two aspects: since the PLD are one of the most recent martian geologic units, any process affecting them must be counted amnong the last alterations of Mars' landscape; if, for instance, the action of surficial water could be proven, this would suppose an upper time limit for the presence of liquid water on Mars' surface. An additional cause of interest is the possibility of a tectonic control on the origin of some of the reentrants; the confmmation of this rypothesis, which was advocated by Benito et al. (1997) for Chasma Boreale and other north polar reentrants, would be to establish a link between the forces acting under Mars' lithosphere and the planet's landscape-shaping processes. Because both kinds of actions involve considerable uncertainties, a joint study could be the best way to shed light on the workings of the martian heat engine. 


\section{CHASMA AUSTRALE MORPHOLOGY}

Chasma Australe originates nearthemartian south pole, forming a topographic step or erosive head cut at $86^{\circ} \mathrm{S} 265^{\circ} \mathrm{W}$. The canyon main head scarp is a prominent amphitheater about $500 \mathrm{~m}$ high and $20 \mathrm{~km}$ wide with a symmetrical semicircular planform. This head cut is about half the size of Chasma Boreale's main scarp. The scarp bottom area contains a secondary scarp which replicates the semicircular planform of the main one although with a shorter curvature radius, and which is followed by a closed depression. Further up the head, a series of straight troughs cutting the polar linear scarps can be followed along $150 \mathrm{~km}$ from this point and up to $88^{\bullet} 30^{\prime} \mathrm{S}, 270^{\circ} \mathrm{W}$ (Fig. 1a). In the opposite direction, about $50 \mathrm{~km}$ down the head scarp, the chasma bottom reaches an older surface unit, which crops out as a rugged terrain resembling the butte-and-basin topography described for the Channeled Scabland of eastern Washington (Baker 1973); on Earth, this kind of topography resulted from severe erosion processes due to the failure of ice-dammed glacial Lake Missoula during the Late Pleistocene (Benito 1997). On Chasma Australe's left (westem) bank, the cliff is truncated in several steps, each one made up of a slightly meandering scarp elongated parallel to the chasma main direction (Fig. 1b). These scarps are irregular in height, with alternating higher and lower sections. Meandering scarps are also developed on the sides of Chasma Borealenear its head cut (see Benito et al. 1997, Fig. 3).

In its middle reaches, Chasma Australe widens up to $100 \mathrm{~km}$ and shows an asymmetric valley section, with a steep eastem margin (up to $1000 \mathrm{~m}$ high) where basal and lateral erosion prevailed, and a gentler western side cutting the PLD at low angles. On this westem side, the stepped topography and spurs have favored deposition. These spurs follow a semicircular pattern that can be interpreted as a severely eroded impact crater with incomplete rims. Deposition apparently occurred at patches downstream from the bottom obstructions and it can be recognized by a higher albedo and a smoother surficial topography. A probable eddy zone deposition is found on the downstream segment of this area (Fig. 1c); here, sedimentation occurs on the PLD and on the underlying unit as well, truncating the bandedcolor pattem typical of the layered deposits. These accumulation areas are also characterized by a smooth surface topography and highly degraded and diffused craters and crater rims (Fig. 1d).

In the broad, terminal part of the chasma, a geological unit (probably a wrinkle ridge) crops out under the form of a resistant spur which partially closes the chasma mouth. Between this ridge and the chasma western bank, a higher albedo zone marks a large depositional area where sediments cover either the PLD or the underlying geological unit. The relief of the eastern part of the ridge is noticeably lower than the rest, attesting to an intense erosion at the foot of the chasma eastem bank. Several craters also show eroded rims at this area, where the topography, with degraded spurs surrounded by flat buttes and closed depressions, again resembles the butte-and-basin scabland typical of the cataclysmic Missoula flooding in eastern Washington.
In the distal reaches of Chasma Australe's eastem margin, a hanging chamel-like feature directed into marginal areas is carved out in the PLD (Fig. 1e). This channel branches off in two different ones, the western one eroding the rim of a large $(80 \mathrm{~km}$ across) impact crater and the eastern one falling into an erosional reentrant carved out on the PLD outside the chasma. Erosion of the crater rim western section gives a distinctly asymmetric crater cross section, with a height difference of more than $500 \mathrm{~m}$ between the eastern and westem rims (see cross sections XS3 and XS4 inFig. 2). This marked crater rim asymmetry is unlikely to have been produced by the impact process itself, but seems rather the result of the attrition caused by a powerful erosive agent. It should nevertheless be noted that whereas this crater appears deeply eroded, their secondary, which pockmark the chasma bottom, look fresh, with slight or no erosion.

\section{A FLUVIAL INTERPRETATION}

Notwithstanding the fact that Chasma Australe is not a typical outflow channel, a set of erosional and depositional features that may be explained through a catastrophic outflow has been identified by means of a detailed geomorphological analysis (Fig. 2). On Earth, horseshoe-shaped cliffs at canyon heads have been found to be caused by concentrated groundwater outflow or sapping (Baker and Milton 1974). On the contrary, this is a feature difficult to explain as due to wind action. In general, terrestrial transverse scarps have been interpreted (e.g., in Late Pleistocene Missoula flooding) as instances of headward recession of subfluvial cataracts (Baker 1978). A typical process associated with this cataract recession is the development beneath the cliffs of closed depressions (plunge pools), formed by water tearing out the bedrock. We propose this origin for the $10-\mathrm{km}$-wide closed depression located at the base of Chasma Australe horseshoe-shaped head cut. The head cut could have acted as a funnel, efficiently concentrating and drawing down the water flow, a process which resulted in an intense macroturbulent scour beneath the cliff.

In Earth analogs, headward recession of scabland cataracts produced distinct inner channels (Baker 1978). In fact, the relatively narrow (c. $20 \mathrm{~km}$ ) head cut width of Chasma Australe, compared to $100 \mathrm{~km}$ in its middle reaches, may be considered as a huge inner channel formed by the headward recession process. Although it could be explained through an eolian process, the meandering aspect of the left bank downstream from the head cut could also be interpreted as a distinct hydrodynamic shape due to cutbank erosion widening the chamel.

Downstream from this narrow head area, the wider, asymmetric cross section of Chasma Australe could be the result of the action of a fluid undercutting the concave eastern valley side, thus shaping a steeper and deeper margin, whereas along the convex western side the flow energy would be lower, producing less erosion and even deposition. Furthermore, other depositional (low energy) areas occur along Chasma Australe, such as flow separation zones (which result in eddy deposits), accumulations 


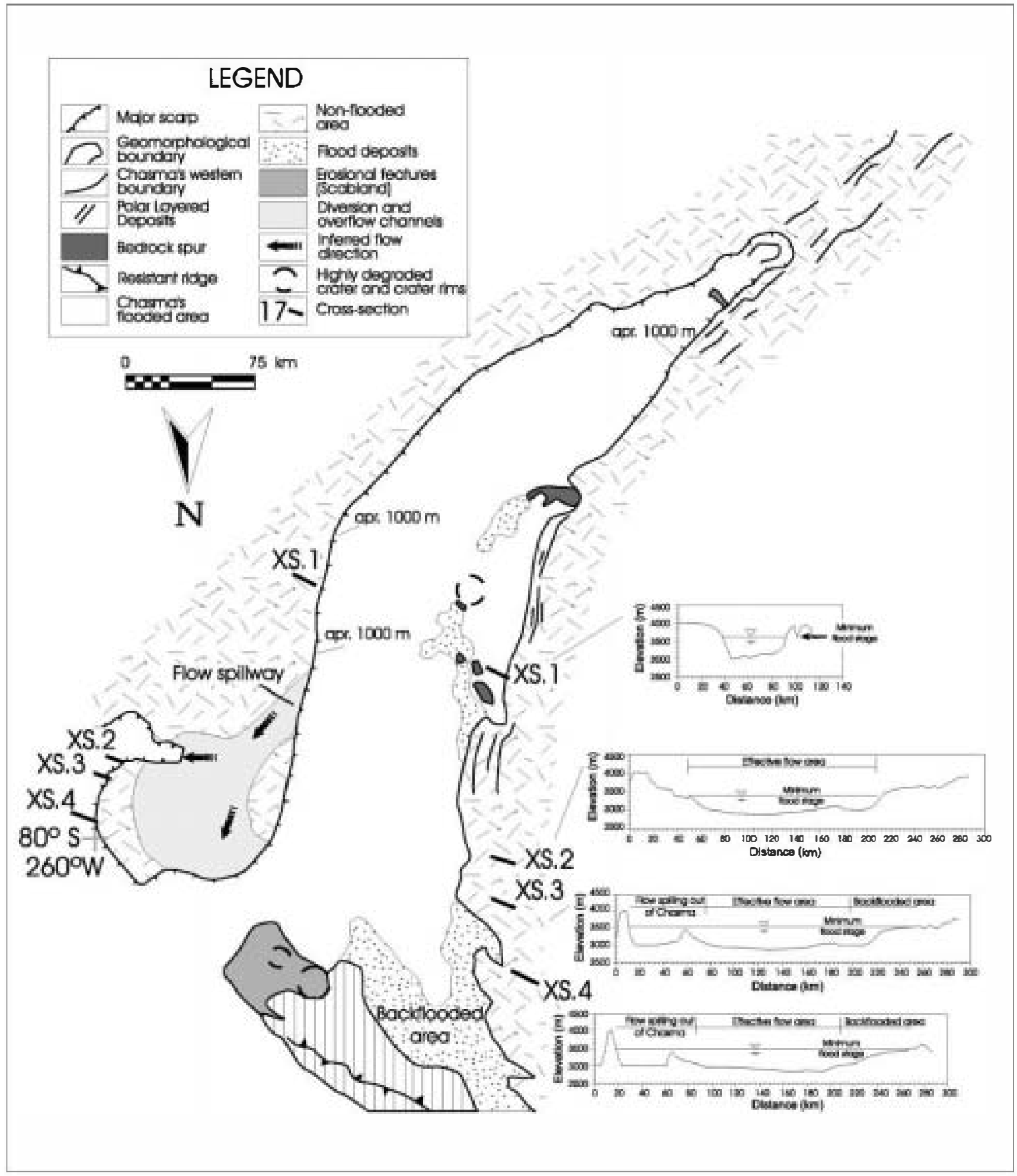

FIG. 2. Geomorphølog ic map of Chasma Australe, including the cross sections (XS1 t॰ 4) where discharge estimations have been carried out 
leeward of bedrock obstacles (pendant accumulations), and backflooded areas on Chasma Australe reentrants. These features, and especially the asymmetric canyon section and backflood sedimentation, are difficult to explain through wind action.

\section{PALEOHYDROLOGICAL RECONSTRUCTION}

The systematic mapping of erosional and depositional features provides minimum, maximum, and ranges of flood stages and flow depths. Four cross sections were drawn using the Mars Digital Model data in areas with the most representative valley morphology. The discharge estimation was calculated using the Manning equation, modified according to Komar (1979). This adapted equation accounts for the smaller gravity existing on Mars, and the flow average velocity takes the expression,

$$
v=\left(\frac{g_{\mathrm{m}} R_{\mathrm{s}}}{C_{\mathrm{f}}}\right)^{\frac{1}{2}}
$$

where $v$ represents velocity of the flow $\left(\mathrm{m} \mathrm{s}^{-1}\right), g_{\mathrm{m}}$ Mars' gravity $\left(\mathrm{m} \mathrm{s}^{-2}\right), R$ hydraulic radius (wetted area/wetted perimeter (m)), $s$ channel bed slope $\left(\mathrm{m} \mathrm{m}^{-1}\right)$, and $C_{\mathrm{f}}$ a coefficient defined as

$$
C_{\mathrm{f}}=g_{\mathrm{e}}\left(n^{2} R^{-\frac{1}{3}}\right)
$$

with $g_{\mathrm{e}}$ being Earth's gravity $\left(\mathrm{m} \mathrm{s}^{-2}\right)$, and $n$ the Manning roughness coefficient.

In the four selected cross sections (Fig. 2), the effective flow area (flow in the downstream direction) has been considered separately from the parts of the channel that do not actively participate in conveying the discharge. These regions of ineffective flow include areas behind prominent spurs, and marginal zones with expected secondary flow such as eddy and backflooded areas. Paleostage indicators used in each cross section correspond to different flood features. Key features among those include depositional areas in cross section XS1, floodwater scouring, high-level divide crossing, and spilling into a high level channel in cross section XS2, severe crater rim erosion in cross sections XS3 and XS4, and accumulation at a backflooded area in cross section XS4. Three factors are of great importance in the calculations of the velocity and discharge: the channel slope $(s)$, the depth reached by the flow $(\boldsymbol{d})$, and the rouglmess coefficient (n). Channel slopes at the different cross sections are comprised between $0.0018^{\circ}$ and $0.0013^{\circ}$, amounts similar to those of many large terrestrial meandering rivers. Water depths shown by the preserved flood indicators are quite consistent from all cross sections, varying between 436 and $624 \mathrm{~m}$. Since the roughness coefficient incorporates the highest degree of uncertainty (not only in Mars but also in Earth analogs), we have performed a sensitivity analysis using the rouglmess coefficient ranges indicated by Komar (1979) for Mars: 0.030 to 0.050 (Table I). This sensitivity test shows that the rouglmess coefficient is of relatively minimal importance for themodeled discharge results.
TABLE I

\begin{tabular}{|c|c|c|}
\hline Mamning's $n$ & Velocity $\left(\mathrm{m} \mathrm{s}^{-1}\right)$ & Discharge $\left(10^{8} \mathrm{~m}^{3} \mathrm{~s}^{-1}\right)$ \\
\hline \multicolumn{3}{|c|}{ Cross section 1} \\
\hline \multirow{2}{*}{\multicolumn{3}{|c|}{$\begin{array}{c}\text { Water depth, } 624 \mathrm{~m} \\
\text { Channel slope, } 0.0018^{\bullet}\end{array}$}} \\
\hline & & \\
\hline 0.03 & 49 & 11.7 \\
\hline 0.035 & 42 & 10 \\
\hline 0.04 & 37 & 8.8 \\
\hline 0.045 & 32 & 7.8 \\
\hline 0.05 & 29 & 7 \\
\hline \multicolumn{3}{|c|}{ Cross section 2} \\
\hline \multicolumn{3}{|c|}{ Water depth, $436 \mathrm{~m}$} \\
\hline \multicolumn{3}{|c|}{ Channel slope, $0.0018^{\bullet}$} \\
\hline 0.03 & 35 & 10.8 \\
\hline 0.035 & 30 & 9.3 \\
\hline 0.04 & 27 & 8.1 \\
\hline 0.045 & 24 & 7.2 \\
\hline 0.05 & 21 & 6.5 \\
\hline \multicolumn{3}{|c|}{ Cross section 3} \\
\hline \multicolumn{3}{|c|}{ Water depth, $590 \mathrm{~m}$} \\
\hline \multicolumn{3}{|c|}{ Channel slope, $0.0013^{\bullet}$} \\
\hline 0.03 & 42 & 29.2 \\
\hline 0.035 & 36 & 25 \\
\hline 0.04 & 31 & 21.9 \\
\hline 0.045 & 28 & 19.5 \\
\hline 0.05 & 25 & 17.5 \\
\hline \multicolumn{3}{|c|}{ Cross section 4} \\
\hline \multicolumn{3}{|c|}{ Water depth, $605 \mathrm{~m}$} \\
\hline \multicolumn{3}{|c|}{ Channel slope, $0.0018^{\bullet}$} \\
\hline 0.03 & 43 & 28.5 \\
\hline 0.035 & 37 & 24.4 \\
\hline 0.04 & 33 & 21.4 \\
\hline 0.045 & 29 & 19 \\
\hline 0.05 & 26 & 17.1 \\
\hline
\end{tabular}

Results of the Discharge Estimations

The water velocity values range between 30 and $50 \mathrm{~m} \mathrm{~s}^{-1}$, while the resulting discharge values oscillate between $7 \times 10^{8}$ and $3 \times 10^{9} \mathrm{~m}^{3} \mathrm{~s}^{-1}$, bracketed by the indicated ranges of roughness coefficients. The obtained values are much less disperse than those calculated by Benito et al. (1997) for Chasma Boreale, which were between 5 and $74 \mathrm{~m} \mathrm{~s}^{-1}$ for the velocity and between $8 \times 10^{7}$ and $1.4 \times 10^{9} \mathrm{~m}^{3} \mathrm{~s}^{-1}$ for the discharge. Chasma Australe discharge rates are of the same order of the estimates for Kasei Vallis, the largest equatorial outflow channel (Robinson and Tanaka 1990), and for Ares Vallis (Komatsu and Baker 1997). In Ares Vallis, Komatsu and Baker (1997) assumed that the water surface reached the rims of the channel, an assumption that may have caused an overestimation of the inferred discharge. Using Mars Orbiter Laser Altimeter topography, Smith et al. (1998) obtained for Ares Vallis a discharge estimate of $5 \times 10^{9} \mathrm{~m}^{3} \mathrm{~s}^{-1}$ (slope channel $=0.002^{\bullet}$ ), or the same order of magnitude as our estimate for Chasma Australe. Komatsu and Baker (1997) and Smith et al. (1998) obtained respective flow velocities of 149 and $142 \mathrm{~m} \mathrm{~s}^{-1}$, which together with a channel depth of $1300 \mathrm{~m}$ yielded a Froude Number $\left[\mathrm{Fr}=v /(\boldsymbol{h} / \boldsymbol{g})^{1 / 2}\right.$, 


\section{TABLE II}

Comparison of the Hydrologic Characteristics of Chasma Australe Putative Subglacial Lake and Lake Vostok, Antarctica

\begin{tabular}{lccc}
\hline \multicolumn{1}{c}{ Subglacial lake } & $\begin{array}{c}\text { Lake volume } \\
\left(\mathrm{km}^{3}\right)\end{array}$ & $\begin{array}{c}\text { Water depth } \\
(\mathrm{m})\end{array}$ & $\begin{array}{c}\text { Qverlying ice } \\
\text { thickmess (m) }\end{array}$ \\
\hline Chasma Australe, Mars & $?$ & $\sim 500$ & $<1200$ \\
$\begin{array}{c}\text { Lake Vostok, Antarctica } \\
\text { (Kapitza et al. 1996) }\end{array}$ & 1800 & Max.510 & 3700 \\
\hline
\end{tabular}

where $h$ is the channel depth and $g$ is gravity] of 2.0 , indicating supercritical flow. The Froude number for Chasma Australe varies between 2 and 3.5, indicating also supercritical flow conditions in the studied cross sections.

A catastrophic flow has been the preferred hypothesis for the origin of the equatorial martian outflow channels (among others, Baker and Kochel 1979, Komar 1979, Mars Channel Working Group 1983, Robinson and Tanaka 1990, and Komatsu and Baker 1997), although Cabrol et al. (1998) have recently proposed pulses of underground flow and headwater retreat sapping processes to explain a series of stepped terraces and tributary valleys in Ma'adim Vallis. These studies provide the basis for cons raining the water budget in Mars history. However, the paleoflow modeling of these outflow channels has been focused on the estimation of peak discharges, some major uncertainties being the water volume and the flow duration required to carve out the channels.

The hypothesis we propose for Chasma Australe is of outburst water flows (jökulhlaups) released from a subglacial lake. Among the terrestrial analogs of sub-ice lakes, the most remarkable one is Lake Vostok in Antarctica (Table II), which presents a planform similar to Chasma Australe. Lake Vostok maximum water depth is $510 \mathrm{~m}$ and the ice thickness confining the lake is c. $3700 \mathrm{~m}$ (Kapitza et al. 1996). In the case of Chasma Australe, we may speculate that the water depth may be equal to or lower than the Chasma's head cut height (c. $500 \mathrm{~m}$ ) and, considering that the maximum thickness of the south polar ice cap shown by MOLA is c. $1700 \mathrm{~m}$, the maximum ice cover confining the sub-ice lake may reach $1200 \mathrm{~m}$. In the bottom of the subglacial lake, the hydraulic pressure would be the equivalent to a head of water close to $1750 \mathrm{~m}$. Under these conditions, we may envisage a sudden drainage of probably only a few days. Flow duration for Pleistocene cataclysmic flooding such as the one from Lake Missoula (Baker 1973, O'Connor and Baker 1992, Benito 1997) or Lake Kuray (Baker et al. 1993) were estimated in about 70 and $30 \mathrm{~h}$, respectively (Table III). Given the large numerical uncertainties and the lack of terrestrial analogs of subglacial lake failures, we consider that any further estimations should wait for new data on the martian poles.

\section{PLANUM AUSTRALE TECTONICS}

In order to determine if there is a relationship between Chasma Australe and any possible tectonic elements present near Mars' south pole, a perusal of the Viking mosaics between $65^{\circ}$ and $90^{\circ} \mathrm{S}$, and from $240^{\circ}$ to $120^{\circ} \mathrm{W}$ was carried out in search of tectonic structures. In all, some 20 million $\mathrm{km}^{2}$ were revised. The result was the identification of 316 lineaments (a part of which were mapped by Scott and Dohm (1990)). Of these, 85 were wrinkle ridges, and the rest straight linear structures up to $100 \mathrm{~km}$ long and without positive relief, which we have given the generic name of fractures. The wrinkle ridges, assumed to be an expression of reverse faults (Plescia and Golombek 1986), are best represented in the longitudes 280 through $335^{\circ} \mathrm{W}$, and from 63 to $70^{\circ} \mathrm{S}$ (Fig. 3). As proposed by Chicarro et al. (1985) and Watters (1988) for the Tharsis area, the ridges are in many cases regularly spaced, with a mean distance between of $50 \mathrm{~km}$. Like in other areas of Mars, they display a characteristic meandering layout.

The strike of these lineaments has been obtained using the Wulff net, with a different size for every latitude from $65^{\circ}$ to $90^{\circ} \mathrm{S}$. When a pole of the net is placed over the south pole of the map, the net $\mathrm{N}-\mathrm{S}$ diameter represents the $\mathrm{N}-\mathrm{S}$ direction, its outer circle is the E-W direction, and the great circles starting at the pole of the net and placed between the outer circle and the $\mathrm{N}-\mathrm{S}$ meridian represent the intermediate orientations. Since the great circles in the net are displayed every $2^{\bullet}$, to determine

TABLE III

Hydrologic Characteristics of Some Cataclysmic Outburst Floodings on Earth and the Estimated Parameters for Chasma Australe

\begin{tabular}{|c|c|c|c|c|}
\hline Cutburst flood & $\begin{array}{l}\text { Lake volume } \\
\qquad\left(\mathrm{km}^{3}\right)\end{array}$ & $\begin{array}{l}\text { Water depth } \\
\text { at dam (m) }\end{array}$ & $\begin{array}{l}\text { Peak discharge } \\
\qquad\left(\mathrm{m}^{3} \mathrm{~s}^{-1}\right)\end{array}$ & $\begin{array}{c}\text { Flow } \\
\text { duration }(\mathrm{h})\end{array}$ \\
\hline Chasma Australe, Mars & $?$ & 500 & $0.7-3 \times 10^{9}$ & $?$ \\
\hline $\begin{array}{l}\text { Kuray flood, Siberia } \\
\text { (Baker et al. 1993) }\end{array}$ & 1000 & 600 & $18 \times 10^{6}$ & 30 \\
\hline $\begin{array}{l}\text { Largest Missoula flood (s) } \\
\text { ('Connor and Baker 1992) }\end{array}$ & 2184 & 635 & $17 \times 10^{6}$ & 70 \\
\hline $\begin{array}{l}\text { Bonneville flood } \\
\text { ('Connor 1993) }\end{array}$ & 4750 & 108 & $1 \times 10^{6}$ & 2640 \\
\hline
\end{tabular}




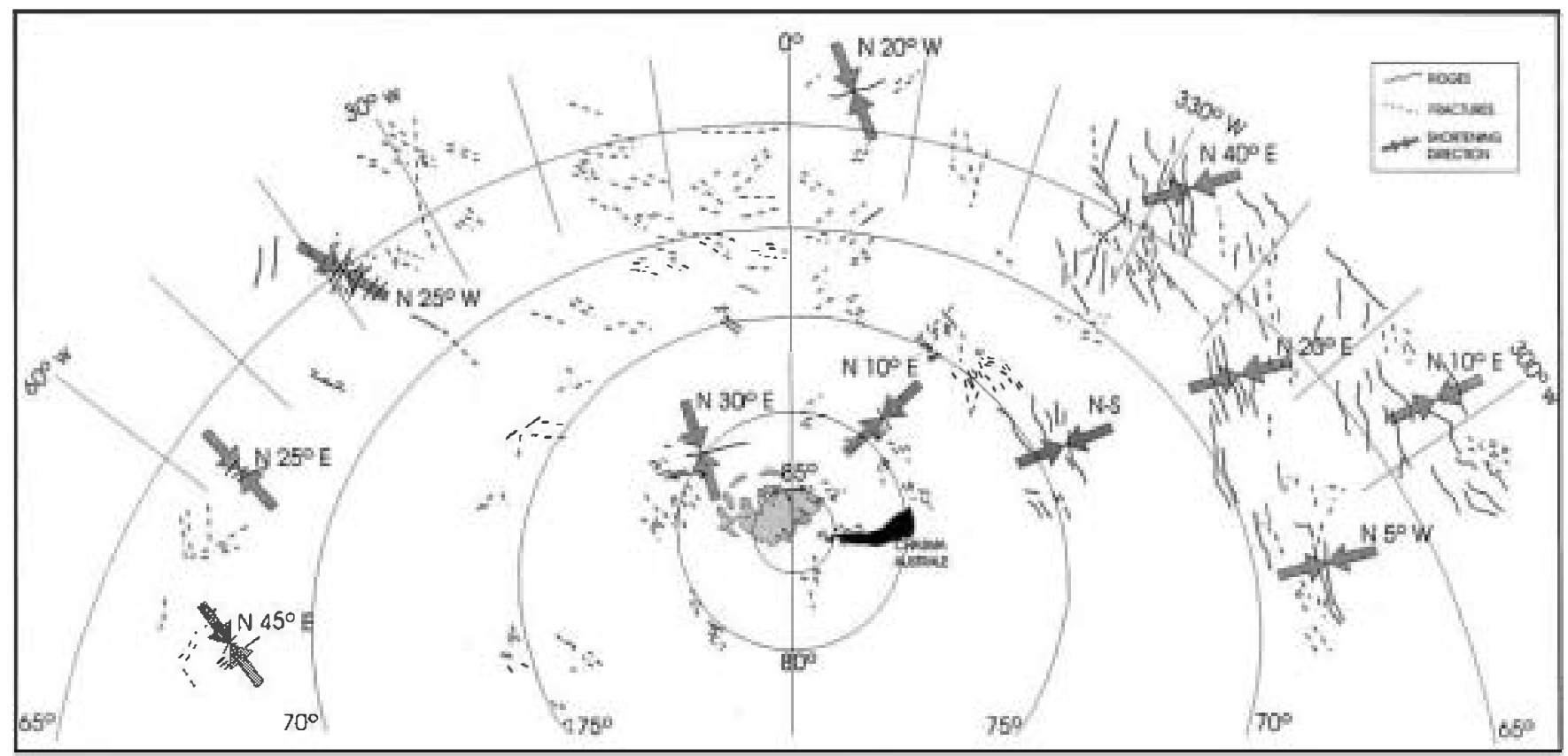

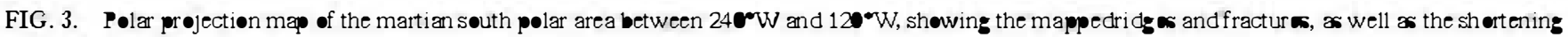
diroctions deduced from them

the strike of a linearnent one must find the great circle that fits it best and then calculate its angular vahe between the N-S diameter and the great circle.

Two rose diagrams have thes been constructed (Fig. 4), one for the wrinkle ridges and the other for the rest of the fractures. The latter one shows three maxima at (in order of importance) $35^{\circ} \mathrm{E}, 135^{\circ} \mathrm{E}$, and $10^{\circ} \mathrm{E}$. The wrinkle ridges are more homogeneous, with a single maximn at $130^{\circ} \mathrm{E}$. An inspection of a topographic map of Mars' south pole shows that a mumber of polar roughs and reentrants on the PLD follow these directions: Chasma Aus rale mean directionis $10^{\circ} \mathrm{E}$, and the longest roughs are oriented at $130^{\circ}-135^{\circ} \mathrm{E}$, a fact that points out to a possible tectonic conrol for at least a part of these features.
All the orientations located can be explained by means of a single compressive stress field. Assuming that wrinkle ridges were due to pure compression, the mean direction of shortening has been calculated at several points of the area studied (see Fig. 4). From these shortening directions, anew rose diagramhas been drawn, whichshows a distinct maximm at $10^{\circ} \mathrm{E}$. For this shortening direction, the fractures grouped around $135^{\circ} \mathrm{E}$ would correspond toreversefaults, whereas the $10^{\circ}$ and $35^{\circ} \mathrm{E}$ lineations would be respectively right- and left-hand strike-slip fractures. Thus, the three observed fracture groups could be explained as the result of a single stress field. In our opinion, this grouping, and the irmportant sufface studied, exchude the possibility that the tectonic structureshave a local, evenaregional, cause. Withelms
FRACTURRS

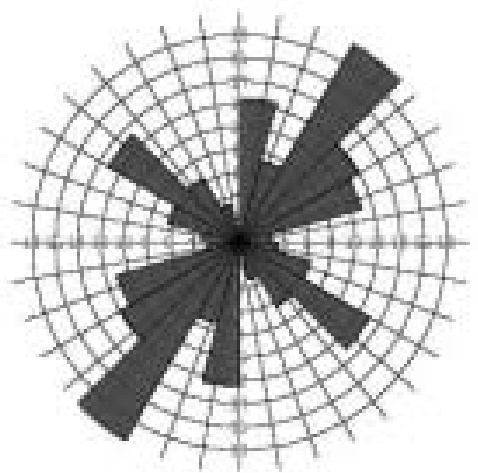

RIDGES

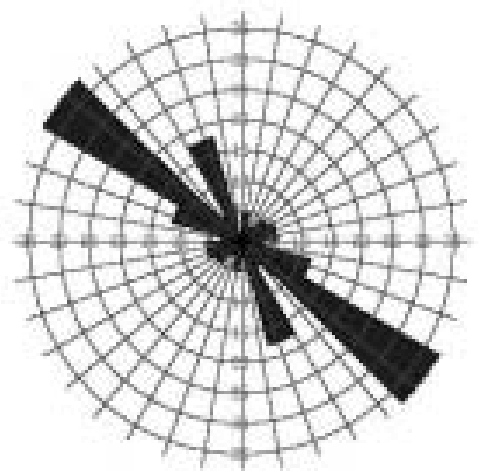

COMPRESSION

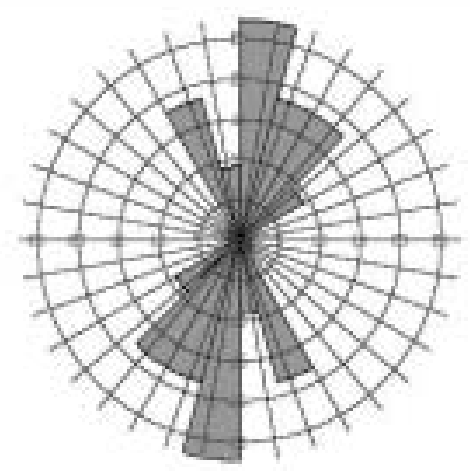

FIG. 4. Rose diagrams showing the orientations of the fracturas, the wrinkle ridges, and the maximum shortening diroction 
(1973) defined a huge $(1000 \mathrm{~km}$ in diameter) impact basin partly covered by the south polar PLD and, with a partially visible rim, Promethei Rupes; but the lineations are neither radial nor concentric to this structure.

To justify this stress field is by no means easy, because the investigations dedicated to the study of extra-Tharsis Mars' tectonics do not abound. Schultz and Lutz (1988) put forward the hypothesis, then followed by Melosh (1980), and Chicarro et al. (1985), that Mars' rotational axis had suffered one or more reorientations which had put stresses on the planet lithosphere. Those stresses would explain all the wrinkle ridges and other fractures unrelated to Tharsis or impact basins. Nevertheless, when contrasted with the measured lineations, this idea is far from satisfactory: the model in Melosh (1980), for instance, proposes N-S-trending thrust faults at polar zones, totally at odds with the general E-W directions of the wrinkle ridges that we have studied. Moreover, Grimm and Solomon (1986) raised serious objections against the rotational overturn idea, which should have left important paleoclimatic evidence. Although Schultz and Lutz (1988) have presented putative examples of that evidence, this is by no means clear.

An altemative hypothesis was presented by Sleep (1994). In this, and during a short period ( $\sim 100 \mathrm{Ma}$ ?) in Hesperian times, the martian lithosphere was divided into two mobile plates. The Boreal plate subducted under the Austral plate along the dichotomy, giving rise to the Tharsis volcanoes and other martian important features. This hypothetical, limited plate tectonics could explain global stresses on the lithosphere. However, movement about the rotation pole proposed by Sleep (1994), located at $23^{\circ} \mathrm{N}, 287^{\circ} \mathrm{W}$, would produce in the south polar area between $0^{\circ}$ and $280^{\circ} \mathrm{W}$ longitude (where most wrinkle ridges are located; see Fig. 3) a NW-SE shortening direction instead of the $\mathrm{N}-\mathrm{S}$ shortening direction that we have deduced. To explain the observed tectonics, the rotation pole should have been at $0^{\bullet} \mathrm{N}$, $230^{\circ} \mathrm{W}$; but in such case the distribution of oceanic ridges, subduction zones, and transform faults in the model proposed by Sleep (1994) would not be valid. This leaves us with two possibilities: either the Sleep (1994) model is not valid because it is unable to explain the south polar structures, or it is valid for the martian northern hemisphere only, perhaps because the Hesperian martian lithosphere did not work as an efficient stress guide up to the southem polar latitudes.

Both alternatives, and the limitations of the rotational reorientation model, leave the intense martian south polar tectonics without an explanation. As other martian features, this one will have to wait until better data, or better ideas, arrive.

\section{CHASMA AUSTRALE: AN OUTFLOW HYPOTHESIS}

Given the coincidence in strike between Chasma Australe and one of the main tectonic lineations detected in the south polar area, we propose a tectonic forcing on this feature. Having in account the morphological evidence for a massive water flow found on the bottom, walls, and marginal areas of the chasma, we propose for the genesis of this accident a mechanism of catastrophic outflow preceded by a tectonically induced intense sapping process.

These indications are multiple, as follows:

- a horseshoe-shaped cliff at the chasma head

- a closed depression under the cliff

- a narrow upper section, as is usual when a retreating head process has been acting

-repeated examples of butte-and-basin topography on the bottom

-different instances of leeward, eddy zone, and backflood sedimentation

- a record of spilling into another, high-level charmel

- a differential erosion case (that of a crater rim) of more than $500 \mathrm{~m}$.

To this morphological evidence should be added the results of the numerical estimates, from which two coincidences stand out:

- the estimated hydraulic parameters with the most recent estimates for martian outflow channels

- the scale of Chasma Australe flood hydrograph with those of jökulhlaups

The idea is similar to the one put forward for Chasma Boreale by Benito et al. (1997): the structural lines would bring the heat of a deep magmatic focus to the base of the polar cap. The localized melt would lead to the formation of a subglacial lake with a structurally conditioned subglacial flow inducing a powerful sapping action. Occasional, probably tectonic, breaks of this reservoir would result in catastrophic outflows. The magnitude and duration of the estimated flow are such that, if confirmed, we contend that they could have had a planetary significance, since they would affect Mars global climate for at least short time spans.

\section{DISCUSSION}

On the basis of MOLA data, Zuber et al. (1998) have recently proposed that Chasma Australe was eroded by the wind. This paper joins an abundant bibliography reating eolian processes on Mars. Many workers (Arvidson et al. 1979, Breed et al. 1979, French and Gierasch 1979, Tsoar et al. 1979, Thomas 1981, 1982, Ward and Doyle 1983, Christensen 1988, Plaut et al. 1988, Thomas and Weitz 1989, Lancaster and Greeley 1990, Greeley et al. 1992, Edgett and Christensen 1994, and Thomas and Gierasch 1995, among others) emphasized the importance of the wind and the wind deposits; some of them (e.g., Cutts 1973a,b, Howard 1978, or Howard et al. 1982) advanced hypotheses favoring the erosion by wind of the polar reentrants.

To discuss this issue, we will present the main morphological features and make a comparative assessment of the merits of each agent, water and wind, to explain it: 
- Planform. Straight in the upper and middle reaches, in sections up to $180 \mathrm{~km}$ long, and radial to the geographic pole. An additional, shallower stretch of $100 \mathrm{~km}$ further up the main head is also straight.

Evaluation: As shown in the structural study, the straight sections are evidence of tectonic forcing. This would favor water (more liable than wind to follow structural lines of weakness) as an agent. On the other side, the radial orientation to the pole could be an argument for an eolian origin, but if this is taken as an evidence then the question is why this is the only south polar reentrant radial to the pole.

- Head. Horseshoe-shaped cliff $500 \mathrm{~m}$ high.

Evaluation: A typical shape of watercourses, especially when out of equilibrium. Unknown on Earth as a wind-shaped feature. The question remains open, however, on the origin of the rest of horseshoe-shaped reentrant heads carved out on the PLD.

- Closed depression in the upper reaches. Near the cliff base, $10 \mathrm{~km}$ across.

Evaluation: This shape could be explained by any one of both agents: water (a plunge pool) or wind (a deflation depression).

- Rugged topography on areas of the bottom. Irregular mounds kilometers to tens of kilometers across.

Evaluation: They could be butte-and-basin (scabland) topography or wind polished residual landforms, though they lack the parallel orientation that characterizes the yardang fields. As for the absence of streamlined landforms found in the equatorial outflow channels, we should keep in mind that on Earth (e.g., the Missoula flooding) these forms are associated to shallow waters, which we contend was not the case of Chasma Australe.

- Depositional zones on the chasma bottom. Leeward of obstacles, eddy zones, backflooded areas.

Evaluation: The first type could be equally well explained as eolian or water-lain; the last two are typical of watercourses diverted by an obstacle.

- Marginal flow. Traces of flow $400 \mathrm{~m}$ higher than the floor of the main valley. They can be followed for $100 \mathrm{~km}$.

Evaluation: It could be explained through wind erosion, or else to be a case of water spilling from the main channel.

- Differential erosion. The rim of an impact crater $80 \mathrm{~km}$ across was eroded differentially: the part of the rim located in the valley mouth is $500 \mathrm{~m}$ lower than the part outside the valley.

Evaluation: Easy to explain as a case of severe erosion by a powerful water flow. On the contrary, it is difficult to see how wind could have eroded selectively two nearby parts of the same rock.

- Bottom erosion. Some secondary craters on the middle reaches bottom are perfectly preserved.

Evaluation: This observation seems to favor wind erosion; the wind would have selectively eroded the PLD but would have been unable to scour the underlying, harder rock. Nevertheless, this hypothesis is difficult to match with the severe erosion of the primary crater described in the previous point.

- Location of the sediments carved out from the chasma. A plain some $150,000 \mathrm{~km}^{2}$ between Chasma Australe mouth

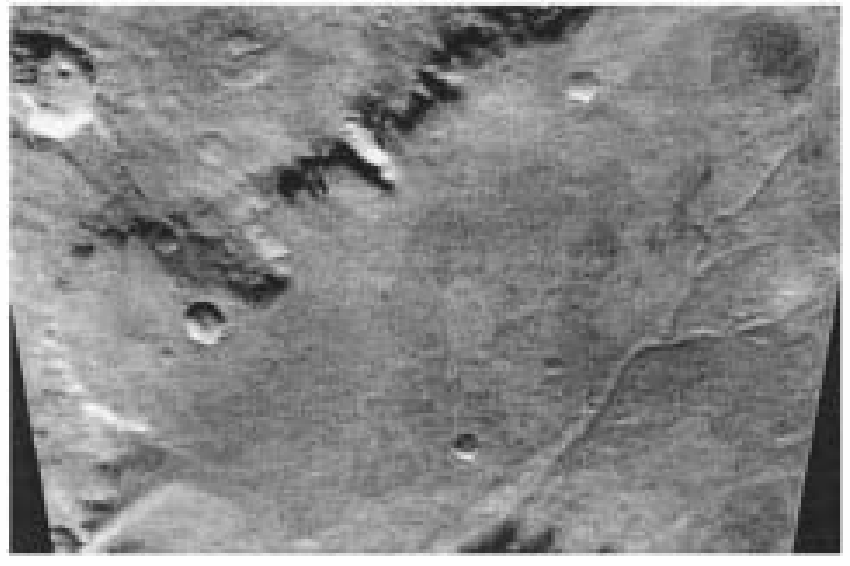

FIG. 5. A quasi-dendritic drainage network eroding a soft material $100 \mathrm{~km}$ away from the mouth of Chasma Australe and at the foot of Promethei Rupes. A part of Viking mosaic centered at $80^{\bullet} \mathrm{S}, 310^{\bullet} \mathrm{W}$. Image width, $200 \mathrm{~km}$. North is up.

and Promethei Rupes could be the present destination of those deposits.

Evaluation: No accumulations of alluvial fan or delta types are found at the mouth. No dune fields exist either on this area (Thomas and Weitz 1989, Thomas and Gierasch 1995). This absence of accumulation favors an eolian hypothesis. In any case, and whatever the carving process, the mouth sediments could have been dispersed by the wind or by latter flows of water. A dendritic network $160 \mathrm{~km}$ long (coordinates: $80^{\circ}-82^{\bullet} \mathrm{S}$, $300^{\circ}-310^{\circ} \mathrm{W}$; Fig. 5) carved out on these deposits shows that water flowed in the area after the formation of Chasma Australe.

The main problem of the outflow hypothesis is the absence of volcanism around Mars' south pole. Two ways out of this difficulty are: (a) the magmatic source came near the surface but never cropped out, its heat being carried out to the surface through the fracture system; (b) the regional geothermal flux would be sufficient to melt the ice. In any case, this same model (Benito et al. 1997) explains the erosive and sedimentological characteristics of Chasma Boreale, where there are no volcanic traces either. Another of the processes implied, sapping, is also difficult to document in Chasma Australe.

Regarding the tectonics of the south polar area, several important questions remain unsolved. We already outlined the problem of the origin of the stresses that created the wrinkle ridges and other lineations. The important amount of surface scrutinized, the number of structures found, and the azimuth homogeneity of these, they all speak about a global phenomena. Thus we seem to be dealing with a compressive field (1) of planetary dimensions (and as such unrelated to any regional accident, as could be an impact basin), and (2) directed from the north (therefore not easily attributable to causes such as tidal braking). As we commented in a previous section, none of the hypotheses presented up to here seems to solve the problem of the origin of this field. One additional problem of our tectonic model is that 
an important number of the measured faults would be strikeslip ones, a type of fracture rarely detected on Mars (Carr 1974, Banerdt et al. 1982, Golombek 1985, Watters and Golombek 1989, Tanaka et al. 1991; but see also Forsythe and Zimbelman 1988, and Schultz 1989, for the only acknowledged examples). We have found no evidence for strike-s lip movement associated with the polar lineaments; nevertheless, a current study by the authors is revealing many new examples of transcurrent faulting on Mars, a planet with a still scarcely understood tectonics.

\section{CONCLUSIONS}

1. The result of a tectonic search of a 20 million $\mathrm{km}^{2}$ area around Mars' south pole has been the detection of a high number of tectonic structures which reveal a stress field of probable planetary scale, with a N-S shortening direction. The origin of this field, which deforms Hesperian age volcanic plains, is unknown.

2. Chasma Australe is a canyon carved out in the PLD whose direction is coincident with one of the statistical directions of the tectonic lineations; therefore, its layout could be tectonically controlled.

3. Seven lines of geomorphological evidence support a catastrophic outflow origin for Chasma Australe: a horseshoe-shaped head with a closed depression on its bottom; a long, narrow upper section; butte-and-basin bottom topography; backflood sedimentation; high-level spilling out; and severe differential erosion.

4. The estimation of the hydraulic parameters of Chasma Australe coincides with those for martian outflow channels; and the flood hydrograph seems to be a scaling up of some Earth jökulhlaups (outflows related to the breaking out of an ice dam).

\section{ACKNOWLEDGMENTS}

Dr. Michael Camr, leader of the Viling Image Team, and the World Data Center A for Rockets and Satellites are gratefully acknowledged for the use of the Viking frames. Two of the authors (F.A. and G.B.) were supported by Grant APC 1997-0046 of CICYT, Spain. The thorough reviews of Victor Baker and Steve Clifford greatly improved (and tempere a bit) the original manuscript.

\section{REFERENCES}

Arvidson, R. E., E. A. Gujnness, andS. Lee 1979. Differential aeolian redistribution rates on Mars. Nature 278, 533-535.

Baker, V. R. 1973. Paleohydrologyand sedimentology of Lake Missoula flooding in eastem Washington. Geological Society of America Special Paper 144

Baker, V. R. 1978. Large-scale erosional and depositional features of the ChanneledScabland. In The Channeled Scabland (V. R. Baker and D. Nummedal, Eds.), pp. 81-115. NASA Office of Space Science Planetary Geology Program, Washington, DC

Baker, V. R., and R. C. Kochel 1979. Martian channel morphology: Maja and Kasei Valles. J. Geophys. Res. 84, 7961-7983.

Baker, V. R., and D. J. Milton 1974. Erosion by catastrophic flood on Mars and Earth. Icarus 23, 27-41.

Baker, V. R., G. Benito, and A. N. Rudoy 1993. Paleohydrology of Late Pleistocene superflooding, Altay Mountains, Siberia. Science 259, 348-350.
Banerdt, W. B., R. J. Phillips, N. H. Sleep, and R. S. Saunders 1982. Thick shell tectonics on one-plate plamets: Applications to Mars. J. Geophys. Res. 87, 9723-9733

Benito, G. 1997. Energy expenditure and geomorphic work of the cataclysmic Missoula flooding in the Columbia River Gorge, USA. Earth Surf. Processes Land forms 22, 457-472.

Benito, G., F. Mediavilla, M. Fernán dez, A. Márquez,J . Martúnez, andF. Anguita 1997. Chasma Boreale, Mars: A sapping and outflow channel with a tectonothermal origin. Icarus 129, 528-538.

Breed, C. S., M. J. Grolier, and J. F. McCauley 1979. Morphology and disribution of conmon "sand" dunes on Mars: Comparison with the Earth. J. Geophys. Res. 84, 8183-8204.

Cabrol, N. A., E. A. Grin, and R. Landheim 1998. Ma'adjm Vallis evolution: Geometry and models of discharge rate. Icarus 132, 362-377.

Carr, M. 1974. Tectonism and volcanism of the Tharsis region of Mars. J. Geophys. Res. 79, 3943-3949.

Chicarro, A. F., P. M. Schultz, and P. Masson 1985. Global and regional ridge pattems on Mars. Icarus 63, 153-174.

Clifford, S. M. 1980. Chasma Boreale $\left(85^{\bullet} \mathrm{N}, 0^{\bullet} \mathrm{W}\right)$ : Renunant of a martian jökulhlaup? Bull. Am. Astron. Soc. 12, 678.

Clifford, S. M. 1987. Polar basal melting on Mars. J. Geophys. Res. 92, $9135-$ 9152.

Christensen, P. R. 1988. Global albedo variation on Mars: Implications for active aeolian transport, deposition, and erosion. J. Geophys. Res. 93, 76117624.

Cutts, J. A. 1973a. Wind erosion in the martian polar regions. J. Geophys. Res. 78, 4211-4221

Cutts, J. A. 1973b. Nature and origin of layered deposits of the martian polar regions. J. Geophys. Res. 78, 4231-4249.

Edgett, K.S., and P. R. Christensen 1994. Mars aeoliansan d: Regional variations amnong dark-hue crater floor features. J. Geophys. Res. 99, 1997-2018.

Forsythe, R. D., and J. R. Zimbelman 1988. Is the Gordii Dorsum escarpment on Mars an exhumed ranscurrent fault? Nature 336, 143-146.

French, R. G., and P. J. Gierasch 1979. The martian polar vortex: Theory of seasonal variation and observations of eolian features. J. Geophys. Res. 84, 4634-4642.

Golombek, M. P. 1985. Fault type predictions from stress distributions on planetary surfaces: Importance of fault initiation depth. J. Geophys. Res. 90, 30653074 .

Greeley, R., N. Lancaster, S. Lee, and P. Thomas 1992. Martian aeolian processes, sediments, and features. In Mars (H. Kieffer, B. M. Jakosky, C. W. Snyder, and M. S. Mathews, Eds.), pp. 730-766. Univ. of Arizona Press, Tucson.

Grimm, R. E., andS. C. Solomon 1986. Tectonic tests of proposed polar wander paths for Mars and the Moon. Icarus 65, 110-121.

Howard, A. D. 1978. Origin of the stepped topography of the martian poles. Icarus 34, 581-599.

Howard, A. D., J. A. Cutts, and K. R. Blasius 1982. Stratigraphic relationships within martian polar cap deposits. Icarus 50, 161-215.

Kapitsa, A. P., J. K. Ridley, G de Q. Robin, M. J. Siegert, and I. A. Zotikov 1996. A large deep freshwater lake beneath the ice of central East Antarctica. Nature 381, 684-686.

Komar, P. D. 1979. Comparison of the hydraulics of water flows in martian outflow charmels with flows of similar scale on Earth. Icarus 37, 156-181.

Komatsu, G., and V. R. Baker 1997. Paleohydrology and flood geomorphology of Ares Vallis. J. Geophys. Res. 102, 4151-4160.

Lancaster, N., and R. Greeley 1990. Sediment volume in the north polar sand seas of Mars. J. Geophys. Res. 95, 10,921-10,927.

Mars Charmel Working Group 1983. Channels and valleys on Mars. Geol. Soc. Am. Bull. 94, 1035-1054. 
Melosh, H. J. 1980. Tectonic pattems on a reoriented planet: Mars. Icarus 44, 745-751.

- 'Connor, J. E., and V. R. Baker 1992. Magnitudes and implications of peak discharges from Glacial Lake Missoula Geol. Soc. Am. Bull. 104, 267-279.

Plant, J. J., R. Kalın, E. A. Gujnness, and R. E. Arvidson 1988. Accumulation of sedimentary debris in the south polar region of Mars and implications for climate history. Icarus 76, 357-377.

Plescia, J. B., and M. P. Golombek 1986. Origin of planetary wrinkle ridges based on the study of terrestrial analogs. Geol. Soc. Am. Bull. 97, 1289-1299.

Robinson, M. S., and K. L. Tanaka 1990. Magnitude of a catastrophic flood event at Kasei Vallis, Mars. Geology 18, 902-905.

Schultz, R. A. 1989. Srike-slip faulting of ridged plains near Valles Marineris, Mars. Nature 341, 424-426.

Schultz, P. H., and A. B. Lutz 1988. Polar wandering on Mars. Icarus 73, 91-141.

Scott, D. H., and J. M. Dohrn 1990. Chronology and global distribution of fault andridge systems on Mars. Proc. Lunar Planet. Sci. Conf. 20th, 487-501.

Sleep, N. H. 1994. Martian plate tectonics. J. Geophys. Res. 99, 5639-5655.

Smith, D. E., M. T.Zuber, H.W. Frey, J. B. Garvin, J. W. Head, D. - Muhleman, G. H. Pettengill, R. J. Phillips, S. C. Solomon, H. J. Zwally, W. B. Banerdt, and T. C. Duxbury 1998. Topography of the Northern Hemisphere of Mars from the Mars Orbiter Laser Altimeter. Science 279, 1686-1692.

Tanaka, K. L., and D. H. Scott 1987. Geologic Map of the Polar Regions of Mars, Map 1-1802-C. US. Geological Survey, Deparment of the Interior, Washington, DC.

Tanaka, K. L., M. P. Golombek, andW. B. Banerdt 1991. Reconciliation of stress and structural histories of the Tharsis region of Mars. J. Geophys. Res. 96, $15,617-15,633$

Thomas, P. 1981. North-south asymmery of eolian features in martian polar regions: Analysis base on crater-related wind markers. Icarus 48, 76-90.

Thomas, P. 1982. Present wind activity on Mars: Relation to large latitudinally zoned sediment deposits. J. Geophys. Res. 87, 9999-10,008.

Thomas, P.C., and P. J. Gierasch 1995. Polar margin dunes and winds on Mars. J. Geophys. Res. 100, 5397-5406.

Thomas, P., andC. Weitz 1989. Sand dine materials and polar layered deposits on Mars. Icarus 81, 185-215.

Tsoar, H., R. Greeley, and A. R. Peterfreund 1979. Mars: The north polar sand sea and related wind pattems. J. Geophys. Res. 84, 8167-8180.

Wallace, D., andC. Sagan 1979. Evaporation of ice in planetary atmospheres: Ice-covere drivers on Mars. Icarus 39, 385-400.

Ward, A. W., and K. B. Doyle 1983. Speculation on martian north polar wind circulation and resultant orientations of polar sand dines. Icarus 55, 420-431.

Watters, T. R. 1988. Wrinkle ridge assemblages on the terrestrial planets. J. Geophys. Res. 93, 10,236-10,254.

Watters, T. R., andM. P. Golombek (Eds.) 1989. MEVTV Works hop on Tect onic Features on Mars, LPI Technical Report 89-06. Lunar and Planetary Science Institute, Houston, TX.

Wilhelms, D. E. 1973. Comparison of martian and lunar multiringed basins. J. Geophys. Res. 78, 4084-4095.

Zuber, M. T., and 20 colleagues 1998 . Observations of the north polar region of Mars from the Mars orbiter laser altimeter. Science 282, 2053-2060. 